\title{
Er schizofrenitermen moden for skraphaugen?
}

\author{
Mange meiner at schizofrenitermen bør bytast ut, medan andre er meir skeptiske til eit namneskifte. Men det \\ er eitt aspekt ved medisinske fagtermar som begge sider ser ut til å oversjå: Ord har ikkje berre tydingsinn- \\ hald, dei har òg brukseigenskapar. Dei termane som er føreslegne som avløysartermar for schizofreni, er nok \\ nøye gjennomtenkte innhaldsmessig, men dei er ikkje særleg språkleg fleksible.
}

Helga Mannsåker

helga.mannsaker@uib.no

Debatten om avskaffing av schizofrenitermen (eventuelt òg schizofreniomgrepet) går både nasjonalt (1) og internasjonalt (2). I Sør-Korea, Japan, Hongkong og Taiwan har ein allereie bytt ut termen (2).

Argumenta som vert nytta av dei som vil erstatte schizofreni med ein ny term, kan delast $i$ to kategoriar. Den eine argumentkategorien dreiar seg om informasjonsverdien til termen, dvs. korleis sjukdomstermen relaterer seg til sjukdomsfenomenet. Desse argumenta går ut på at termen schizofreni er fagleg upresis og misvisande fordi han ikkje lenger reflekterer den forståinga fagfeltet har av fenomenet som han gjev namn til. Den andre argumentkategorien dreiar seg om konnotasjonane (assosiasjonane) til termen. Her finn vi argument som går ut på at termen schizofreni er belasta og belastande for høvesvis lekfolk og pasientar $(3,4)$. Men éin argumentkategori ser ut til å mangle i debatten: språklege brukseigenskapar. Fagtermar varierer når det gjeld kor godt dei eignar seg som base for danning av nye ord og kva typar setningskonstruksjonar dei kan inngå i. Dette har konsekvensar for kor kortfatta og kor variert ein kan uttrykkje seg om det aktuelle emnet. Ideelt sett bør ein avløysarterm vere både dekkjande, ikkjestigmatiserande og brukarvennleg - tre ulike kriterium som det ikkje utan vidare er lett å kombinere.

I det følgjande vil eg drøfte dei tre argumentkategoriane kvar for seg. Innleiingsvis vil eg presisere at det er viktig å skilje mellom schizofrenitermen og schizofreniomgrepet. Førstnemnde refererer til fagordet schizofreni, som stammar frå 1908, sistnemnde til vår tids faglege forståing og avgrensing av det sjukdomsfenomenet (syndromet) som fagordet schizofreni enn så lenge vert nytta for å referere til. Ein kan i teorien velje mellom å byte ut fagordet, men behalde sjukdomsomgrepet, behalde fagordet, men byte ut sjukdomsomgrepet, eller byte ut både fagordet og sjukdomsomgrepet. Det er schizofrenitermen som er tema for mi drøfting. Eg tek derfor ikkje stilling til validiteten, reliabiliteten eller nytteverdien til schizofreniomgrepet.

\section{Informasjonsverdi}

Det er ikkje første gongen det psykiatriske fagfeltet vurderer å byte namn på sjukdomsfenomenet. Termen schizofreni vart lansert av Paul Eugen Bleuler (1857-1939) i 1908 som avløysarterm for det dåverande sjukdomsnamnet dementia praecox (5), som var blitt introdusert av Emil Kraepelin (1856-1926) nokre år tidlegare, og som i skandinavisk hadde ungdomssløvsinn som

\section{«Termen schizofreni er fagleg upresis og misvisande fordi han ikkje lenger reflekterer den forståinga fagfeltet har av fenomenet som han gjev namn til»}

synonym. Bleuler argumenterte for at schizofreni var meir dekkjande, då han vurderte «splittinga av dei psykiske funksjonane» som eit kardinalsymptom for heile sjukdomsgruppa (schizofreni er samansett av gresk skhizein «kløyve» og phren «sinn»). Dementia praecox («prematur demens») var ifølgje Bleuler eit misvisande namn, fordi sjukdommen korkje nødvendigvis forte til demens eller braut ut i ung alder.

Det synet at eit sjukdomsnamn skal reflektere noko sant om fenomenet det refererer til, ser ut til å rå grunnen i medisinen òg i dag (6), og det vert trekt fram av begge sider i namnebytedebatten. Tilhengarane av namnebyte hevdar at namnet schizofreni reflekterer ein utdatert forståingsmodell og derfor er misvisande. Motstandarane viser til at det (enno) ikkje har kome noko stort gjennombrot i schizofreniforskinga som har gjeve oss innsyn i kva som er kjernen i fenomenet. Sjølv om fagfeltet ikkje lenger skulle vurdere «splitting av psykiske funksjonar» som eit sentralt og definerande trekk ved schizofreni, er det vanskeleg å finne ein dekkjande internasjonal erstatningsterm som alle kan einast om. Jamfør Kraepelin anno 1909, som vedgår at namnet dementia praecox var eit uheldig og misvisande val (7). Han åtvarar mot å gje sjukdommen eit kunnskapsbasert namn før ein har nådd fram til ei tilstrekkeleg forståing, og rår til å velje eit inkjeseiande mellombels namn som erstatning for dementia praecox - eit råd fagfeltet ikkje tok til følgje.

\section{Konnotasjonar}

Bleuler og Kraepelin var mest opptekne av informasjonsverdien, men konnotasjonsargument vert no meir og meir vektlagde. Idealet er at fagspråk ikkje skal verke stigmatiserande. Dersom ein fagterm vert for belasta, belastande eller misbrukt av lekfolk, kan han bli bytt ut, jamfør lagnaden til termen psykopat(i).

Schizofrenitermen har negative assosiasjonar som mellom anna vert forsterka av media $(8,9)$, som til dømes at schizofreni er einstydande med «splitta personlegdom» og at menneske diagnostiserte med schizofreni er farlege og aldri kan bli friske att (10).

Det er blitt hevda at schizofrenitermen er meiningslaus (11). Termen er kanskje misvisande, men slett ikkje meiningslaus: Schizofreni tyder bokstaveleg «splitta sinn» og er dermed kompatibel med ideen om det delte sjølvet, som er blitt kalla ein grunnleggjande semantisk konfigurasjon i språket (12), og som mellom anna gjer at NRK kan kalle ein TV-serie om psykiske vanskar Jeg mot meg, som om sinnet består av fleire distinkte individ. Dette kan forklare misoppfatninga av schizofreni som «splitta personlegdom» og den utbreidde metaforiske bruken av sjukdomstermen i daglegspråket, i tydinga «indre motsetnadar, inkonsistens». Denne tydinga av ordet er førebels ikkje blitt teken inn i korkje Bokmålsordboka eller Nynorskordboka, men oxforddictionaries.com fører 
opp denne tydinga for både schizophrenia og schizophrenic. Det at schizofrenitermen i si bokstavelege tyding refererer til splitting av sinnet og dermed gjev assosiasjonar om inkonsistens og splitta personlegdom, forsterkar truleg den stigmatiserings- og sjølvstigmatiseringsproblematikken som heftar ved diagnosen.

\section{Brukseigenskapar}

Bleuler hadde i 1908 òg bruksbaserte argument for at schizofreni skulle erstatta dementia praecox. Medan greskbaserte termar som schizofreni, hebefreni og katatoni eignar seg godt som utgangspunkt for danning av nye ord, er termen dementia praecox eit latinsk fleirleddsuttrykk som er vanskeleg å bruke i germanske språk (13). Han består av eit substantiv etterfølgt av eit adjektiv («demens prematur»), og han eignar seg dårleg til orddanning.

Innføringa av erstatningstermen schizofreni gav fagfeltet høve til å danne ei rekkje relaterte fagord, som schizofren, schizofreniform, schizofrenispektrumtilstand, preschizofren $(i), i k k(j) e$-schizofren med fleire. Denne brukseigenskapen var etterlengta i fagfeltet. Psykiateren Hans Evensen (18681953) klagar til dømes over at dementia praecox er «ildeklingende» og «i sproglig henseende tungt haandterligt, når det skal bruges som tillægsord» (dvs. som adjektiv) (14). Presidenten for den amerikanske medisinsk-psykologiske foreininga trekte i 1919 fram som eit argument for termen schizofreni at ein kan danne adjektiv frå schizofreni, men ikkje frå dementia praecox (15). Bleuler sjølv var av den oppfattinga at ein utførleg differensialdiagnostikk for sjukdomsgruppa utan eit slikt avleidd adjektiv ville vere «schlimm zu schreiben und noch schlimmer zu lesen» (16).

Sjølv om eit avleidd adjektiv stod høgt på ønskelista til fagfeltet $\mathrm{i}$ byrjinga av 1900-talet, har sjukdomsrelaterte adjektiv ei skuggeside som ein i moderne psykiatri generelt er svært medveten om. Eit adjektiv kan rett nok gje høve til språkleg økonomi i drøftingar av differensialdiagnostikk og aspekt ved sjukdommen, som til dømes i uttrykk som schizofrene lidingar og schizofrene og affektive symptom. Men det kan samstundes medføre stigmatisering og sjølvstigmatisering, då adjektivet òg vert nytta for å karakterisere menneske. Adjektivet kan til og med åleine referere til menneske med ein schizofrenidiagnose, som til dømes «dei schizofrene» (17). Substantivet schizofreni kan på si side ikkje åleine referere til personen, men må ha eit personrefererande tillegg, til dømes substantivet pasient i uttrykket schizofrenipasient.

Men dersom eit nytt sjukdomsnamn vert knytt til eit nytt sjukdomsomgrep som framstiller syndromet som per i dag vert kalla schizofreni, på ein meir prognoseoptimistisk og mindre stigmatiserande måte, vil kanskje eit eventuelt nytt avleidd adjektiv vere mindre problematisk? Jamfør til dømes adjektivet deprimert, som er knytt til ein diagnose med relativt god prognose. Er deprimert like problematisk å nytte om menneske som tilfellet er med adjektivet schizofren?

\section{«ldealet er at fagspråk ikkje skal verke stig- matiserande»}

Generelt er orddanningar bruksmessig sett uvurderlege når ein skal skrive vitskapelege og tekniske tekstar, der krava til både presisjon og språkleg økonomi er høge. Tekstinnhaldet må pakkast tett, mellom anna på grunn av strenge maksgrenser på tekstlengd ved publisering. Ein språkbrukar står temmeleg fritt til å lage nye orddanningar ved behov, og mogelegheitene for kombinasjonar med andre ord er nær sagt uendelege, jamfør til dømes schizofreni-mottagelighetsgener (18) og den skizofrene transitivisme (19). I tillegg gjev orddanningar høve til språkleg variasjon ved at ein kan velje mellom fleire alternative måtar å uttrykkje seg på, til dømes schizofrene symptom, schizofrenisymptom, symptom på schizofreni, eventuelt symptom som er assosierte med schizofreni.

Den norske utgåva av «Blåboka» til ICD10 , som inneheld diagnostiske retningslinjer for psykiske lidingar, er eit døme på ein fagtekst som gjer bruk av ulike orddanningar frå schizofrenitermen. Her finn vi uttrykk som mellom anna schizoaffektiv, post-schizofren depresjon, schizofrene symptomer, schizofrene og affektive symptomer, schizofrene lidelser, schizotyp lidelse, latent schizofren reaksjon, akutt schizofrenilignende psykose med fleire. Orddanningar som desse gjer det mogeleg å uttrykkje seg meir fortetta. Alternativa til orddanningsbaserte uttrykk er å nytte preposisjonsuttrykk eller leddsetningar med lågare innhaldsmessig tettleik: postschizofren depresjon kan mogelegvis erstattast med «depresjon etter gjennomgått schizofreni», schizofrenilignende med «som ligner på schizofreni». Andre uttrykk, som til dømes schizoaffektiv, schizofrene lidelser og latent schizofren reaksjon, vil gjerne krevje endå lengre parafraseringar.

Ei rekkje engelskspråklege avløysartermar for schizofreni er føreslegne (2). Dei er alle fleirordsuttrykk som lik dementia praecox ikkje eignar seg spesielt godt til orddanningar. På norsk har psykosespekterlidelse blitt foreslått (1). Denne avløysartermen er sett saman av tre ord og kan berre vanskeleg byggjast vidare ut. Ein avløysarterm for schizofreni som vert presentert lausriven frå autentisk språkbruk, kan sjå brukbar ut i og for seg, og argumenta for at den nye termen betre speglar dagens kunnskap om syndromet på ein ikkje-stigmatiserande måte, kan vere framifrå. Men korleis skal ein laga orddanningar av eller oppnå variert setningsbygnad med føreslegne erstatningstermar som til dømes NeuroEmotional Integration Disorder, Psychosis Susceptibility Syndrome, Dysfunctional Perception Syndrome eller psykosespekterlidelse? Vil nokon av desse termane eigentleg duge i praktisk (språk)bruk, eller vil dei uunngåeleg føre til lengre tekstar med liten språkleg variasjon - tekstar som både er tunge å skrive og tunge å lese?

\section{Helga Mannsåker (f. 1976)}

er stipendiat i nordisk språk ved Universitete i Bergen. Tema for doktorgradsprosjektet er fagspråkleg bruk av termane schizofren og schizofreni.

Forfattaren har fylt ut ICMJE-skjemaet og oppgjev ingen interessekonfliktar.

\section{Litteratur}

1. Thoresen B. - Vi bør slutte å si schizofreni. Psykisk helse 2015; nr. 4. http://psykiskhelse.no/bladet/ 2015/h\%C3\%A5per-vi-slutter-\%C3\%A5-sischizofreni (4.1.2017).

2. Lasalvia A, Penta E, Sartorius N et al. Should the label «schizophrenia» be abandoned? Schizophr Res 2015; 162: 276-84

3. Clement S, Foster N. Newspaper reporting on schizophrenia: a content analysis of five national newspapers at two time points. Schizophr Res 2008; 98: 178-83.

4. Kingdon D, Vincent S, Vincent S et al. Destigmatising schizophrenia: does changing terminology reduce negative attitudes? Psychiatr Bull 2008. 32: 419-22

5. Bleuler E. Die Prognose der Dementia Praecox (Schizophreniegruppe). Allgemeine Zeitschrift für Psychiatrie und psychisch-gerichtliche Medizin 1908; 65: 436-64.

6. Kåss E. (13.2.2009). Eponym. I: Store medisinske leksikon. https://sml.snl.no/eponym (4.1.2017).

7. Kraepelin E. Dementia precox and paraphrenia Oversatt av Mary Barclay. I: Robertson GM, red. Fra 8. tyske utgave av: Psychiatrie: ein Lehrbuch für Studierende und Ärzte (1909), bd. 3, del 2, om endogen demens. Chicago, IL: Chicago medical book co, 1919

8. Anda LG. Mord, galskap og løver - schizofreni i norske aviser. Tidsskrift for Norsk psykologforening 2013; 50: 1154-62.

9. Owen PR. Portrayals of schizophrenia by entertainment media: a content analysis of contemporary movies. Psychiatr Serv 2012; 63: 655-9.

10. Nath D. The schizophrenia stereotype scares the sufferer too. Independent 13.11.2013. www.independent.co.uk/life-style/health-and families/health-news/the-schizophreniastereotype-scares-the-sufferer-too-8937792. html?origin=internalSearch (4.1.2017). 
11. van Os J. 'Salience syndrome' replaces 'schizophrenia' in DSM-V and ICD-11: psychiatry's evidence-based entry into the 21st century? Acta Psychiatr Scand 2009; 120: 363-72.

12. Talmy L. Toward a cognitive semantics. Cambridge, MA: MIT Press, 2000.

13. Wulff HR. Lægevidenskabens sprog: fra Hippokrates til vor tid. København: Munksgaard, 2003.

14. Evensen H. Dementia præcox. Doktoravhandling. Kristiania: Aschehoug, 1904.

15. Noll R. American madness: the rise and fall of dementia praecox. Cambridge, MA: Harvard University Press, 2011.

16. Bleuler E. Dementia Praecox, oder Gruppe der Schizophrenien. Unveränderte Neuauflage der Ausgabe von 1911 (Franz Deuticke). Gießen: Psychosozial-Verlag, 1911/2014.

17. Mannsåker $\mathrm{H}$. Năr berre sjukdommen står att Bergens Tidende 15.11.2016. www.bt.no/ btmeninger/debatt/Nar-berre-sjukdommen-staratt-325887b.html (4.1.2017).

18. Malt UF, Retterstøl N, Dahl AA. Lærebok i psykiatri. 2. utg. Oslo: Gyldendal Akademisk, 2003.

19. Parnas J, Kragh-Sørensen P, Mors 0 et al. Klinisk psykiatri. 3. utg. København: Munksgaard, 2009.

Motteke 7.10. 2016, første revisjon sendt inn 5.1. 2017, godkjent 13.1. 2017. Redaktør: Erlend Hem. 